\title{
Clinical treatment of corneal infection due to Fonsecaea pedrosoi - Case report
}

\section{Tratamento de infecção corneana causado pelo Fonsecaea pedrosoi - Relato decaso}

\author{
Ana Luisa Höfling-Lima ${ }^{1}$ \\ Josep Guarro ${ }^{2}$ \\ Denise de Freitas $^{3}$ \\ Patricio Godoy ${ }^{4}$ \\ Josepa Genés \\ Luciene Barbosa de Souza ${ }^{6}$ \\ Luis Zaror ${ }^{7}$ \\ Andre C. Romano
}

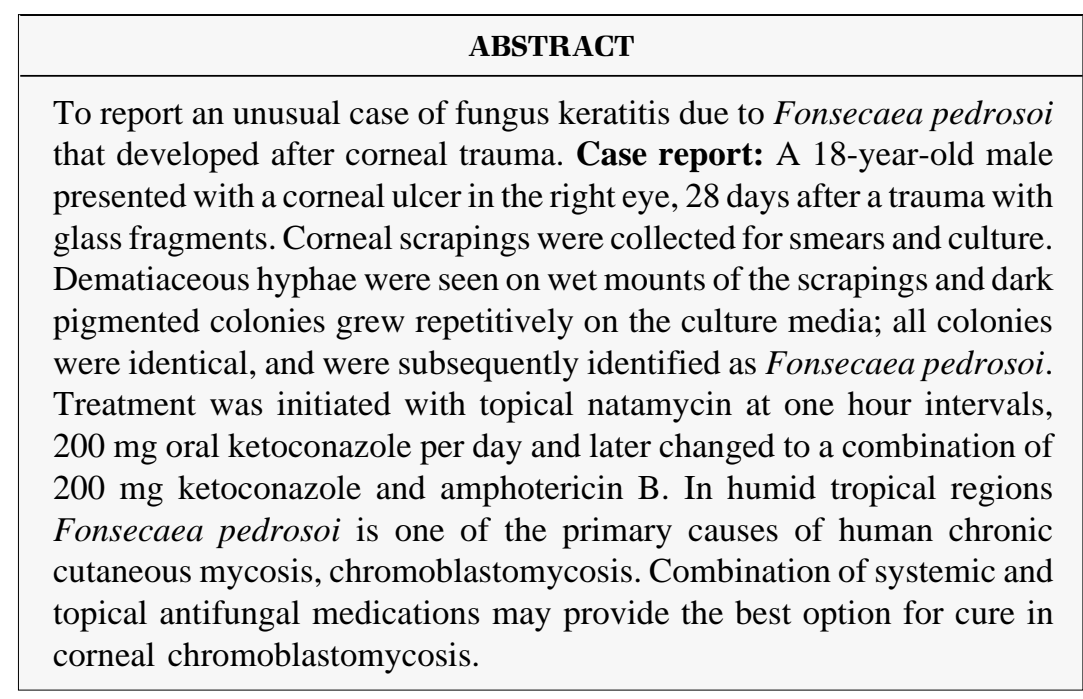

Keywords: Corneal diseases/microbiology; Keratitis/microbiology; Eye injuries/complications; Eye infections, fungal; Antifungal agents/therapeutic use; Mitosporic fungi; Case report

\section{INTRODUCTION}

Fonsecaea pedrosoi is the commonest causative agent of chromoblastomycosis ${ }^{(1)}$, a chronic mycotic cutaneous and subcutaneous skin infection, which primarily occurs in humid tropical regions.

Treatment of the mycosis caused by this agent is unrewarding not only because of the scarcity of effective antifungals but also due to the need for prolonged periods of treatment, which in some reports has required prolonged therapeutic regimens of up to 2 years to obtain a mycologic cure ${ }^{(2)}$. Several studies have indicated, by minimal inhibitory concentration (MIC) values, that itraconazole presents no resistance to Fonsecaea pedrosoi ${ }^{(3)}$.

In the ophthalmic literature, only one previous case of corneal chromoblastomycosis caused by Fonsecaea pedrosoi was reported ${ }^{(4)}$. In the management of that case, two penetrating keratoplasties (PK) were performed, and itraconazole was introduced as the first line option after the first PK and continued for 6 months after second PK when the eye became quiet and the infection controlled. This result correlates with the clinical experience in medical reports, which show that $10 \%$ of chromoblastomycosis patients are not cured in spite of extended courses (20 months) of itraconazole therapy ${ }^{(2)}$.

Corneal chromomycosis not due to Fonsecaea pedrosoi where previously described, with the clear description of management difficulties. The first case (Phialofora verrucosa) was treated with topical thiabendazole, but surgical treatment was not combined with cryotherapy and conjunc- 
tival flap. The second case (Phialofora verrucosa) was treated with keratectomy, conjunctival flap, topical natamycin and a penetrating keratoplasty led to a final visual acuity of 20/60. The third case (Phialofora bubakii) was treated with topical $1 \%$ fluocytosine.

\section{CASE REPORT}

An 18-year-old male was referred to the corneal service in August 2001 with a corneal ulcer of the right eye 28 days after glass trauma to the eye. The patient had been treated with neomycin, ciprofloxacin, and $0.1 \%$ dexamethasone for a week without improvement. His distance visual acuity was 20/400 in the right eye and 20/30 in the left at presentation. Intraocular pressure measured by bimanual examination was normal. There was a 3 x $2 \mathrm{~mm}$ diameter central epithelial defect with feathery borders. The anterior segment showed a mild inflammatory reaction with a few keratic precipitates under the corneal infiltrate. The posterior segment was quiet.

Corneal scrapings were collected for fungus and bacteriologic microscopic examination and culture. Potassium hydroxide mounts and smears with Gram and Giemsa stains were made. Scrapings were inoculated directly onto Sabouraud glucose agar (DIFCO) with chloramphenicol (200 mg/L) and blood agar.

Gram staining showed filamentous structures on the next day.

Neomycin, ciprofloxacin, and $1 \%$ dexamethasone were discontinued and topical natamycin (5\% pimaricin) was initiated hourly along with $200 \mathrm{mg}$ per day oral systemic ketoconazole.

A good reepithelialization of the ulcer was observed 10 days later and natamycin treatment was decreased to application every 2 hours. No rebound inflammatory reaction was noted after dexamethasone was suspended. Two days later, recurrence of the infection was noted and natamycin was restored to every 2 hours. On the next day, dematiaceous hyphae were seen on wet mounts of the scrapings and dark pigmented colonies grew on the culture media; all colonies were identical and were subsequently identified as Fonsecaea pedrosoi.

Natamycin therapy was discontinued and treatment with topical amphotericin B $(0.5 \%)$ was initiated every hour along with the oral ketoconazole. After 100 days the treatment was discontinued because clinical healing occurred. A small central stromal leukoma remained and the final distance visual acuity was 20/200. No relapse of infection was observed three months after the cessation of therapy.

The fungus was cultured on oatmeal agar and showed the typical features of Fonsecaea pedrosoi, i.e. spreading, lanose and olivaceous-green colonies with a blackish reverse. Cultures also showed the two typical morphologic forms ${ }^{(1)}$ : i) light brown conidiophores, profusely branched with cylindrical, intercalary or terminal conidiogenous cells with clusters of prominent denticles and ii) the Phialophora synanamorph, characterized by ampulliform, darker phialides with conspicuous funnel-shaped collarettes. The conidia were smooth-walled, clavate, pale olivaceous and measured 3.5 - 5 x 1.5 - $2 \mu \mathrm{m}$ (Figure 1).

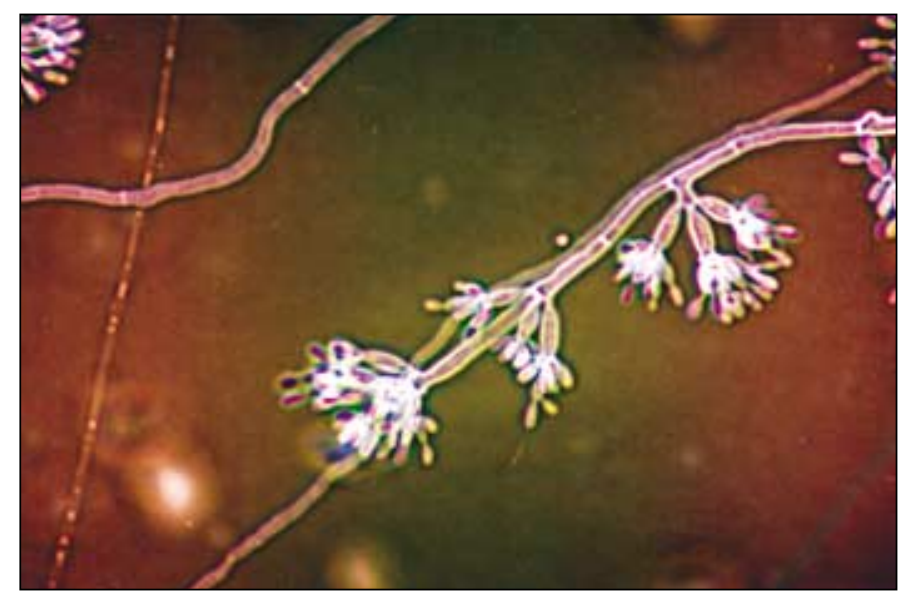

Figura 1 - Fase contrast (Lactophenol - Fonsecaea pedrosoi) 40X

\section{COMMENTARY}

A combination of two antimycotic agents was prescribed to treat this reported case: ketoconazole and amphotericin B. This treatment have led to a quiet state of the infection and apparently cessation of fungal penetration and no relapse of this infection was eminent after termination of therapy. This result might be explained by the MIC levels being lower for amphotericin B than for natamycin in the afore mentioned case report, and ketoconazole being less resistant in our sensitivity testing (see Table 1).

Although in vitro susceptibility testing does not reliably predict in vivo efficacy for fungi, and MICs can not be used as strict guidelines for therapy, the possibility of performing in vitro tests should be considered. In that way, one may avoid ineffective, costly and a prolonged course of treatment. In view of the lack of susceptibility of this agent to the current antimycotic drugs, it may be wiser to seriously consider the possibility of combining the best available drugs in order to obtain a synergistic effect.

The authors open the possibility of clinical treatment for Fonsecaea pedrosoi corneal infection and discuss the importance of determination of MIC levels for antifungal agents.

\begin{tabular}{|c|c|}
\hline Antifungal drug & $\operatorname{MIC}(\mu \mathrm{g} / \mathrm{ml})$ \\
\hline Amphotericin B & 1 \\
\hline Flucitosine & 8 \\
\hline Itraconazole & 0.25 \\
\hline Ketoconazole & 0.03 \\
\hline Voriconazole & 0.03 \\
\hline \multicolumn{2}{|c|}{$\begin{array}{l}\text { Sensitivity testing was performed according to the guidelines of the National } \\
\text { Committee for Clinical Laboratory Standards (NCCLS) for molds }{ }^{5} \text {, using RPM } \\
1640 \text { medium buffered to } \mathrm{pH} 7 \text { with } 0.165 \mathrm{M} \text { morpholinepropanesulfonic acid } \\
\text { (MOPS), an inoculum of } 1.5 \times 10^{6} \mathrm{CFU} / \mathrm{ml} \text {, an incubation temperature of } 30^{\circ} \mathrm{C} \text {, } \\
\text { an incubation time of } 72 \mathrm{~h} \text {, and an additive drug dilutions regimen. }\end{array}$} \\
\hline IC: minimal inhibitor & \\
\hline
\end{tabular}


Further studies should be performed to determine the value of combined topical and systemic clinical treatment and also additional surgical treatment.

\section{ACKNOWLEDGEMENTS}

The authors thank Maria Cecilia Zorat Yu for her help in the laboratory investigation.

\section{RESUMO}

Relato de um caso atípico de infecção fúngica da córnea causada pelo microrganismo Fonsecaea pedrosoi após trauma ocular. Paciente, masculino, estudante de 18 anos, apresentou-se ao Setor de Doenças Externas Oculares do Departamento de Oftalmologia da UNIFESP com úlcera de córnea paracentral de 3,5 x 3,5 mm e aspecto branco-acinzentado com bordas infiltradas, 28 dias após trauma em ocular por vidro. Foi realizado raspado da córnea e o material enviado para análise microbiológica. Foi observado crescimento de colônias em meio de cultura e posteriormente colocadas em solução de lactofenol-azul de algodão. Verificou-se a presença de hifas dermáceas de pigmento escuro, identificado como Fonsecaea pedrosoi. Tratamento foi iniciado com natamicina $5 \%$ tópica a cada hora e cetoconazol $200 \mathrm{mg}$ por dia. Subseqüentemente foi substituído pela combinação cetoconazol e anfotericina B. Fonsecaea pedrosoi é uma das principais causas em humanos de micose crônica cutânea, cromoblastomicose, em regiões úmidas tropicais. A combinação de antimicóticos sistêmicos e tópicos pode ser a melhor opção para pacientes no tratamento de cromoblastomicose da córnea.

Descritores: Doenças da córnea/microbiologia; Ceratite/microbiologia; Traumatismos oculares/complicações; Infecções oculares fúngicas; Antimicóticos/uso terapêutico; Fungos mitospóricos; Relato de caso

\section{REFERENCES}

1. Hoog GS, Guarro J. Gené J, Figueras MJ. Atlas of clinical of fungi. Baarn, The Netherlands; Centraalbureau Voor Schimmelultures - Universitat, Rovira i Virgili, 2000.

2. Esterre P, Andriantsimhavandy A, Ramarcel ER, Pecarrere JL. Forty years of chromoblastomycosis in Madagascar: a review. Am J Trop Med Hyg. 1996; 55(1):45-7.

3. Bedout C de, Gomez BL, Restrepo A. In vitro susceptibility testing of Fonsecaea pedrosoi to antifungals. Rev Inst Med Trop Sao Paulo. 1997;39(3):145-8.

4. Barton K, Miller D, Pflugfelder SC. Corneal chromoblastomycosis. Cornea. 1997;16(2):235-9.

5. National Committes for Clinical Laboratory Standards - NCCLS. Reference method for broth dilution antifungal susceptibility testing of conidium-forming filamentous fungi: proposed standard M38-P. Wayne: NCCLS; 1998. 